\title{
OPTIMASI KONDISI SUHU DAN KELEMBABAN SERTA PENGARUH MEDIA TANAM TERHADAP KEBERHASILAN AKLIMATISASI TANAMAN KARET ASAL EMBRIOGENESIS SOMATIK
}

\author{
Optimization of Temperature and Humidity Condition as well as Effect of Media \\ Composition to the Successful of Rubber Plants Originated from \\ Somatic Embryogenesis Acclimatization
}

\author{
Fetrina OKTAVIA ${ }^{1 *}$, Charlos Togi STEVANUS ${ }^{1}$, dan Florence DESSAILLY ${ }^{2}$ \\ ${ }^{1)}$ Pusat Penelitian Karet \\ Jalan Raya Palembang - Pangkalan Balai KM 29 \\ Sembawa, Banyuasin 30953, Sumatera Selatan \\ *Email : fetrina_oktavia@yahoo.com \\ ${ }^{2)}$ Agricultural Research for Development (CIRAD) \\ 389 Avenue d'Agropolis - TA A-108/03 34398 \\ Montpellier Cedex 5, 34398 France
}

Diterima : 30 April 2020 / Disetujui : 21 Desember 2020

\begin{abstract}
Acclimatization is a critical period in the multiplication of plants through tissue culture. Plantlet mortality due to changes of the environmental condition from in vitro to ex vitro oftenly occur during this period, so effort is needed to manipulate the environmental condition to obtain optimum condition. The research was aimed to optimize the temperature and humidity conditions and to observe the effect of planting media composition which was suitable for acclimatization stage of rubber planting material originated from somatic embryogenesis in the greenhouse. Climate optimization in plastic tunnel was carried out by using the fogging system. Experiment used 210 plantlets of $P B 260$ clones originating from CIRAD, France. Plantlets were planted in seven combination of grow media by using a Completely Randomized Design with three replications, and each replication consisted of ten plants. Observations were made on the percentage of survival plants, height, diameter and number of leaves during acclimatization. Optimization of temperature and humidity in plastic tunnel were successfully carried out under conditions of temperature below $30^{\circ} \mathrm{C}$ and humidity above 90\%. Results showed that type of media influenced the survival ability of plants. The highest survival rate reached $90 \%$ which was resulted by soil and mixture of cocofibre, peat moss and zeolite media. Type of media did not
\end{abstract}

give a significant effect to height, diameter and number of leaves of the plants during two months acclimatization. The significant effect of media type resulted on height of plants on three months after acclimatization. In the limitations conditions of top soil availability, the mixture of cocofibre, peat moss and zeolite could be used as an alternative of substitute planting media for rubber plant.

Keywords: Hevea brasiliensis; juvenility; planting media; rubber seedlings; tissue culture

\section{Abstrak}

Aklimatisasi merupakan periode kritis dalam perbanyakan tanaman melalui kultur jaringan. Kematian planlet akibat terjadinya perubahan kondisi lingkungan dari in vitro ke ex vitro sering terjadi pada periode tersebut, sehingga perlu dilakukan upaya memanipulasi kondisi lingkungan untuk memperoleh kondisi yang optimum. Penelitian bertujuan untuk mengoptimasi kondisi suhu dan kelembaban serta melihat pengaruh komposisi media tanam yang sesuai untuk proses aklimatisasi bibit karet asal embriogenesis somatik di rumah kaca. Optimasi iklim dalam sungkup plastik dilakukan dengan menggunakan alat fogging system. Penelitian menggunakan 210 planlet klon PB 260 yang berasal dari CIRAD, Perancis. Planlet ditanam pada tujuh 
kombinasi media tumbuh menggunakan Rancangan Acak Lengkap (RAK) dengan tiga ulangan dan setiap ulangan terdiri dari sepuluh tanaman. Pengamatan dilakukan terhadap persentase tanaman hidup, tinggi, diameter dan jumlah daun tanaman selama aklimatisasi. Optimasi suhu dan kelembaban dalam sungkup plastik berhasil dilakukan pada kondisi suhu di bawah $30^{\circ} \mathrm{C}$ dan kelembaban di atas $90 \%$. Pengamatan menunjukkan bahwa jenis media berpengaruh terhadap kemampuan tanaman bertahan hidup. Persentase tanaman bertahan hidup mencapai 90\% ditemukan pada media tanah dan campuran cocofiber, gambut dan zeolit. Jenis media tidak berpengaruh nyata terhadap tinggi, diameter dan jumlah daun tanaman selama dua bulan aklimatisasi. Pengaruh nyata jenis media tanam hanya ditemukan terhadap pertumbuhan tinggi tanaman tiga bulan setelah aklimatisasi. Dalam kondisi keterbatasan ketersediaan top soil, campuran media cocofiber, gambut dan zeolit dapat digunakan sebagai alternatif media tanam pengganti untuk tanaman karet.

Kata kunci : Bibit karet; Hevea brasiliensis; juvenilitas; kultur jaringan; media tanam

\section{PENDAHULUAN}

Penggunaan bahan tanam karet unggul merupakan salah satu komponen utama terpenting dalam upaya peningkatan produktivitas perkebunan karet. Hingga saat ini perbanyakan tanaman karet secara konvensional yang paling efektif adalah secara vegetatif menggunakan metode okulasi, dimana pada teknik tersebut dibutuhkan batang bawah dan batang atas (entres). Meskipun sudah sukses digunakan dalam perbanyakan bahan tanam karet secara komersial, aplikasi teknik okulasi masih menghadapi berbagai kendala seperti keterbatasan ketersediaan entres sebagai batang atas, batang bawah, tenaga okulasi terampil, waktu persiapan yang lama, adanya ketidaksesuaian batang atas dan batang bawah serta juvenilitas entres yang rendah yang dapat mempengaruhi pertumbuhan dan produktivitas tanaman.
Pengaruh negatif batang bawah terhadap pertumbuhan dan produksi tanaman karet hasil okulasi sudah banyak dilaporkan (Goncalves \& Martins, 2002; Cardinal et al., 2007). Ketidaksesuaian antara batang atas dan batang bawah dapat menyebabkan terjadinya pembengkakan dan nekrosis pada kulit batang dipertautan okulasi. Hal ini terjadi akibat timbulnya ketidakseimbangan antara produksi senyawa sianogenik dengan kemampuan detoksifikasi antara batang bawah dan batang atas. Adanya variabilitas genetik batang bawah (Clément-Demange et al., 2007) dan ketidaksesuaian batang bawah dan batang atas dapat menghambat pertumbuhan tanaman karet dan menyebabkan penurunan produksi lateks mencapai $40 \%$.

Ketersediaan biji sebagai sumber batang bawah yang terbatas juga merupakan masalah yang cukup penting yang dihadapi dalam perbanyakan tanaman karet secara okulasi pada saat ini. Dengan berkembangnya ilmu pengetahuan di bidang bioteknologi membuka peluang untuk mengatasi hal tersebut dengan menggunakan teknik kultur jaringan melalui embriogenesis somatik (SE). Dengan teknik ini diharapkan bibit karet klon-klon unggul dapat dihasilkan secara massal dan seragam dalam waktu cepat serta kualitas bibit yang lebih terjamin.

Embriogenesis somatik merupakan teknologi kunci dalam penyiapan bahan tanam karet di masa depan (Mignon \& Werbrouck, 2018). Bibit yang dihasilkan dari $\mathrm{SE}$ disebut juga dengan self-rooting juvenile clones karena memiliki perakaran sendiri sehingga terbebas dari ketidasesuaian batang bawah dan batang atas serta memiliki tingkat juvenilitas yang tinggi. Hal ini akan memberikan pengaruh positif terhadap pertumbuhan dan produksi lateks tanaman (Gireesh et al., 2012). Dibi et al. (2010) menyatakan bahwa terjadi peningkatan lilit batang tanaman asal $\mathrm{SE}$ sebesar $16,8 \%$ dan produksi lateks sebesar $32,3 \%$ dibandingkan tanaman asal okulasi. Analisis transkriptom gen-gen yang terlibat dalam mekanisme produksi lateks melalui sekuensing metode Ilumina terlihat bahwa terdapat peningkatan ekspresi gen-gen 
regenerasi dan durasi aliran lateks pada tanaman asal SE dibandingkan dengan tanaman yang diperbanyak secara okulasi (Li et al., 2016).

Keberhasilan sistem perbanyakan bahan tanam karet melalui embriogenesis somatik sudah banyak dilaporkan. Berbagai jenis eksplan telah berhasil digunakan dalam induksi kalus dan embrio somatik yaitu eksplan anther (Wan et al., 1982; Tahardi, 1998; Jayasree et al., 1999), dinding integumen dalam dari biji karet muda (Carron \& Enjarlic, 1985 ; Montoro et al., 2000), akar (Zhou et al., 2010), kotiledon (Dickson et al., 2011), ovul (Jayashree et al., 2011) serta nodus (Sanguansermsri et al., 2015), tunas aksilar dan apikal (Mayati \& Jamnah, 2014). Dari semua jenis eksplan yang sudah digunakan, jaringan dinding integumen dalam dan anther merupakan eksplan yang paling responsif terhadap induksi kalus dan embrio somatik tanaman karet (Mignon \& Werbrouck, 2018). Karena eksplan integumen dalam berasal dari jaringan muda maka secara ontogeni tingkat juvenilitasnya sangat tinggi sehingga dapat meningkatkan kualitas juvenilitas planlet yang dihasilkan (Lardet et al., 2009 ; Monteuuis, 2016). Kedua sumber eksplan tersebut saat ini banyak digunakan pada pengembangan embriogenesis somatik pada berbagai klon karet.

Keberhasilan proses embriogenesis somatik yang menghasilkan planlet secara in vitro harus diikuti dengan keberhasilan proses aklimatisasi. Aklimatisasi merupakan tahapan paling kritis yang menentukan keberhasilan perbanyakan bahan tanam melalui kultur jaringan (Hazarika, 2003; Hazarika et al., 2006; Aronen, 2016; Singh, 2018). Kondisi in vitro seringkali menyebabkan terjadinya perubahan morfologi, anatomi dan fisiologi pada planlet (Chandra et al, 2010), sehingga pada tahapan aklimatisasi planlet memerlukan usaha yang besar untuk menghadapi perubahan tersebut. Pada kondisi in vitro di dalam tabung kultur planlet berada pada kondisi ketersediaan nutrisi yang mudah diserap tanaman serta kondisi lingkungan yang optimal seperti suhu, kelembapan, intensitas cahaya dan aseptik, pada saat dipindah ke kondisi ex vitro di lingkungan luar tanaman harus mampu menyerap dan memproses air dan mineral serta beradaptasi dengan kondisi lingkungan luar yang jauh berbeda dengan kondisi in vitro. Pada kondisi in vitro tanaman tumbuh di bawah intensitas cahaya rendah (1200 - 3000 lux) dengan suhu di bawah $25^{\circ} \mathrm{C}$, sedangkan saat ditransfer ke ex vitro tanaman akan langsung menerima intensitas cahaya yang tinggi (4000 - 12000 lux) dengan suhu yang bisa mencapai $35^{\circ} \mathrm{C}$, sehingga terjadi peningkatan evapotranspirasi yang mengakibatkan tanaman menjadi layu (Lavanya et al., 2009). Persentase kematian tanaman asal kultur jaringan yang cukup tinggi seringkali ditemukan pada tahap ini akibat stres pada tanaman karena organorgan tanaman yang belum berfungsi dengan baik. Selain kondisi iklim lingkungan, penggunaan jenis media tanam yang sesuai juga akan mempengaruhi keberhasilan aklimatisasi (Kaur et al., 2011; El-Zeiny et al., 2013; Barpete et al., 2014).

Untuk mengurangi stres pada tanaman maka pada tahap awal aklimatisasi perlu diupayakan lingkungan ex vitro yang menyerupai lingkungan in vitro. Manipulasi kondisi lingkungan ex vitro tersebut diharapkan mampu mengurangi cekaman terhadap tanaman sehingga tanaman dapat bertahan hidup dan tumbuh dengan baik. Keterbatasan ketersediaan top soil dan tingginya kontaminasi patogen penyebab penyakit akar pada media tanah perlu menjadi pertimbangan utama dalam pemilihan media aklimatisasi tanaman karet. Standar operasional prosedur (SOP) aklimatisasi bibit karet asal embriogenesis somatik (SE) di daerah subtropis sudah dilaporkan oleh CIRAD, Perancis (komunikasi pribadi), namun prosedur tersebut masih perlu disesuaikan dengan kondisi iklim tropis di Indonesia. Penelitian bertujuan untuk mengoptimasi kondisi suhu dan kelembapan udara serta melihat pengaruh berbagai komposisi media tanam terhadap keberhasilan proses aklimatisasi bibit tanaman karet asal SE di iklim tropis.

\section{BAHAN DAN METODE}

Penelitian dilakukan di Rumah Kaca Pusat Penelitian Karet, Sembawa, Banyuasin, Sumatera Selatan pada bulan Januari hingga Juni 2019. Percobaan dilakukan dengan menggunakan bibit tanaman karet asal SE klon PB 260. Embriogenesis somatik (SE) di induksi dari 
ekpslan jaringan integumen dalam yang diambil dari buah muda klon PB 260. Proses perbanyakan dan penyiapan planlet melalui metode embriogenesis somatik sekunder tidak langsung (indirect Secondary Somatic Embryogenesis/SSE) (Lardet et al., 2009) dilakukan di Laboratorium BIOS CIRAD, Perancis dan pengiriman ke Indonesia dilakukan pada tanggal 9 Februari 2019.

Penelitian terdiri dari dua tahap yaitu optimasi kondisi iklim dalam sungkup plastik di rumah kaca dan melihat pengaruh komposisi media tanam terhadap keberhasilan aklimatisasi bibit karet asal SE di rumah kaca.

\section{Optimasi Kondisi Iklim dalam Sungkup Plastik dan Rumah Kaca}

Optimasi kondisi iklim lingkungan pertumbuhan dilakukan dengan cara pencatatan data suhu dan kelembapan udara di dalam rumah kaca dan di luar rumah kaca setiap jam dari pukul 08.00 19.00 WIB selama satu minggu menggunakan alat temperature hygrometer digital (merek BIO APA). Berdasarkan ratarata suhu dan kelembapan tersebut dilakukan pengaturan suhu dan kelembapan di dalam sungkup plastik untuk mendapatkan suhu dan kelembapan optimal untuk aklimatisasi tahap awal bibit karet asal SE. Pengaturan suhu dan kelembaban di dalam sungkup dilakukan dengan cara penyemprotan air dengan fogging system menggunakan alat automatic fogging system (merek Rain Bird@France) ukuran noozle $2 \mu \mathrm{m}$ pada berbagai interval waktu sehingga diperoleh suhu yang kurang dari $30^{\circ} \mathrm{C}$ dan kelembapan di atas $90 \%$. Alat bekerja secara otomatis mengeluarkan kabut air untuk meningkatkan kelembaban udara dan menurunkan suhu dalam sungkup plastik. Pengaturan suhu dan kelembaban udara juga dibantu dengan manual mist system dan sirkulasi udara menggunakan blower di luar sungkup plastik serta penurunan intensitas cahaya menggunakan paranet $50 \%$ dalam rumah kaca. Perlakuan interval waktu fogging system pada penelitian ini adalah :

1. Kontrol (K) : kondisi kelembaban dan suhu di dalam rumah kaca (condition of air humidity and temperature in green house)
2. FS1 : 1 menit fogging system setiap 30 menit (1 minute fogging system every 30 minute)

3. FS $2: 5$ menit fogging system setiap 30 menit (5 minute fogging system every 30 minute)

4. FS $3: 10$ menit fogging system setiap 30 menit (10 minute fogging system every 30 minute)

5. FS 4 : 10 menit fogging system setiap 60 menit + paranet (10 minute fogging system every 60 minute + paranet)

6. FS 5: 10 menit fogging system setiap 30 menit + paranet (10 minute fogging system every 30 minute + paranet)

\section{Pengaruh Komposisi Media terhadap Aklimatisasi Bibit Karet Asal SE dalam Sungkup Plastik di Rumah Kaca}

Percobaan dilakukan pada 210 bibit tanaman karet asal SE menggunakan rancangan acak lengkap (RAL) yang terdiri dari tujuh perlakuan media dengan tiga ulangan. Perlakuan komposisi media tanam ditunjukkan pada Tabel 1. Setiap perlakuan terdiri dari sepuluh tanaman dan tiga ulangan sehingga total tanaman pada setiap perlakuan adalah tiga puluh. Gambut yang digunakan dalam penelitian ini merupakan gambut yang berasal dari Desa Sungei Rengit, Banyuasin, Sumatera Selatan. Tabel 2 menunjukan hasil analisis sifat kimia gambut yang digunakan (Saputra et al., 2018).

Penanaman bibit asal SE dilakukan pada pagi hari untuk mengurangi terjadinya stres akibat suhu yang tinggi. Untuk mengurangi kontaminasi patogen, media tanam diperlakukan dengan penyiraman $100 \mathrm{ml}$ larutan fungisida Dithane $5 \mathrm{~g} / \mathrm{L}$ (Mancozeb 80\%) ke setiap polybag dan akar bibit tanaman dicelup ke dalam larutan fungisida Bayleton $5 \mathrm{~mL} / \mathrm{L}$ (5\%) sebelum ditanam. Tanaman ditempatkan dalam sungkup plastik dengan kelembaban udara di atas $90 \%$ dan suhu di bawah $30^{\circ} \mathrm{C}$ melalui pengaturan automatic mist system berdasarkan hasil percobaan optimasi iklim sebelumnya. Pemeliharaan sanitasi lingkungan dilakukan dengan penyemprotan Anvil $2 \%$ setiap minggu dalam sungkup plastik dan Dithane 5\% di luar sungkup plastik. Tanaman dipelihara dalam sungkup plastik selama 2 bulan, selanjutnya sungkup plastik akan dibuka 
Tabel 1. Komposisi media tanam (MT) yang digunakan pada tahap aklimatisasi bibit tanaman karet asal SE di rumah kaca

Table 1. Composition of planting media (PM) was used on acclimatization stage of rubber planting material originated from SE in the green house

\begin{tabular}{cccccc}
\hline \multirow{2}{*}{$\begin{array}{c}\text { Perlakuan } \\
\text { Treatment }\end{array}$} & Cocofiber & Cocopeat & $\begin{array}{c}\text { Zeolit } \\
\text { Zeolite }\end{array}$ & $\begin{array}{c}\text { Gambut } \\
\text { Peat Moss }\end{array}$ & $\begin{array}{c}\text { Tanah } \\
\text { Soil }\end{array}$ \\
\cline { 2 - 6 } & \multicolumn{5}{c}{ v /v) } \\
\hline Kontrol & 60 & - & 10 & 30 & 100 \\
MT 1 & 50 & - & 10 & 40 & - \\
MT 2 & 40 & - & 10 & 50 & - \\
MT 3 & 60 & 30 & 10 & - & - \\
MT4 & 50 & 40 & 10 & - & - \\
MT 5 & 40 & 50 & 10 & - & - \\
MT 6 & & & & & \\
\hline
\end{tabular}

Tabel 2. Analisis sifat kimia gambut asal Desa Sungei Rengit

Table 2. Chemical properties analysis result of peat at the study site (Sungei Rengit Village)

\begin{tabular}{lcc}
\multicolumn{1}{c}{$\begin{array}{c}\text { Parameter } \\
\text { Parameter }\end{array}$} & $\begin{array}{c}\text { Hasil analisis } \\
\text { Analysis results }\end{array}$ & $\begin{array}{c}\text { Kriteria } \\
\text { Criteria }\end{array}$ \\
\hline $\mathrm{pH} \mathrm{H} \mathrm{H}_{2} \mathrm{O}$ & 4,17 & Sangat masam \\
$\mathrm{C}-$ Organik $(\%)$ & 13,74 & Sangat tinggi \\
$\mathrm{N}(\%)$ & 0,64 & Tinggi \\
$\mathrm{P}_{2} \mathrm{O}_{5}(\mathrm{ppm})$ & 1,28 & Sangat rendah \\
$\mathrm{K}(\mathrm{me} / 100 \mathrm{gr})$ & 0,018 & Sangat rendah \\
$\mathrm{Ca}(\mathrm{me} / 100 \mathrm{gr})$ & 0,35 & Rendah \\
$\mathrm{Mg}(\mathrm{me} / 100 \mathrm{gr})$ & 0,796 & Sedang \\
$\mathrm{KTK}(\mathrm{me} / 100 \mathrm{gr})$ & 87,69 & Sangat tinggi \\
\hline
\end{tabular}

secara bertahap selama 1 bulan sebelum tanaman dikeluarkan sepenuhnya dari sungkup plastik. Parameter yang akan diamati selama tanaman dipelihara dalam sungkup plastik adalah persentase tanaman bertahan hidup, tinggi, diameter dan jumlah daun tanaman.

\section{HASIL DAN PEMBAHASAN}

\section{Optimasi Kondisi Iklim pada Sungkup Plastik dan Rumah Kaca}

Aklimatisasi merupakan periode kritis dalam perbanyakan bibit tanaman secara kultur jaringan. Kegagalan akibat kematian pada periode tersebut sering mengakibatkan kehilangan terbesar planlet dalam proses penyiapan bibit kultur jaringan. Hal ini menyebabkan kesulitan dalam proses aklimatisasi sering kali menjadi kendala utama perbanyakan massal bahan tanam melalui kultur jaringan, terutama pada spesies tanaman berkayu termasuk tanaman karet (Le Conte \& Carron, 1988).

Gambar 1 menunjukkan rata-rata kelembaban udara dan suhu harian yang diukur setiap jam dari pukul 08.00 - 19.00 WIB di dalam rumah kaca dan di luar rumah kaca Pusat Penelitian Karet, Sembawa pada bulan Februari 2019. Kelembaban di dalam dan di luar rumah kaca berkisar $69-88 \%$ dan 60,9-88\% dengan tingkat kelembaban di bawah $80 \%$ pada pukul 09.00 - 16.00 WIB (Gambar 1A). Suhu di dalam rumah kaca berkisar $26-35,4^{\circ} \mathrm{C}$ dan di luar rumah kaca $26-40,7^{\circ} \mathrm{C}$ dengan suhu di atas $30^{\circ} \mathrm{C}$ pada pukul 09.00-16.00 WIB (Gambar 1B). Berdasarkan kondisi kelembaban dan suhu harian tersebut dimana kelembaban di bawah $80 \%$ dan suhu diatas $30^{\circ} \mathrm{C}$ maka diketahui bahwa periode kritis iklim terhadap proses aklimatisasi pada bulan 

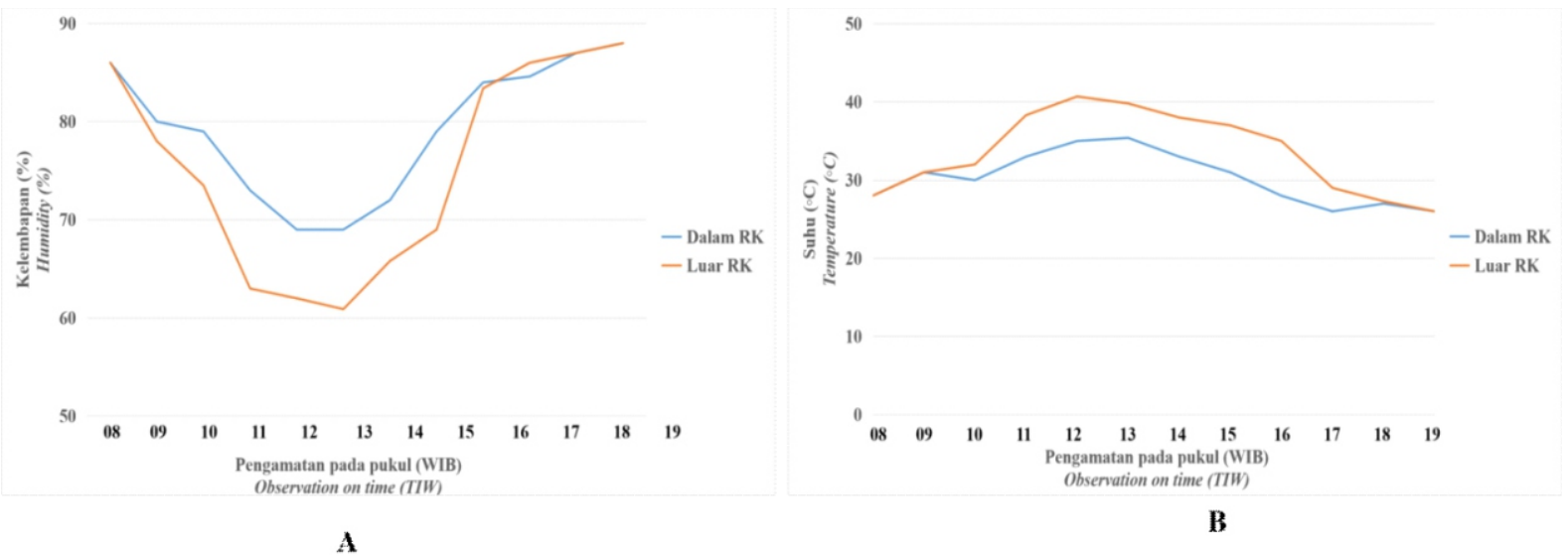

Gambar 1. Rata-rata kelembaban udara (A) dan suhu (B) di dalam dan di luar rumah kaca (RK) Pusat Penelitian Karet, Sembawa dari pukul 08.00 - 19.00 WIB

Figure 1. Average of air humidity (A) and temperature (B) inside and outside of the green house (GH) at Indonesian Rubber Research Institute, Sembawa from 8 am - 7 pm (Western Indonesian Time)

Februari 2019 adalah pada pukul 09.00 16.00 WIB. Informasi tersebut digunakan sebagai dasar dalam optimasi fogging system untuk meningkatkan kelembaban dan menurunkan suhu terutama pada waktuwaktu kritis tersebut.

Gambar 2 menunjukkan peningkatan kelembaban udara dan penurunan suhu dalam sungkup plastik pada berbagai pengaturan interval waktu alat fogging system. Peningkatan kelembaban udara terjadi pada semua perlakuan fogging system. Kelembaban optimal diatas $90 \%$ dicapai pada perlakuan FS 4 dan FS 5 yaitu dengan penyemprotan kabut air selama 10 menit setiap 30 menit dan 10 menit setiap 1 jam dan di atas sungkup plastik ditutup dengan menggunakan paranet (Gambar 2A). Sedangkan penurunan suhu terjadi pada perlakuan FS 2. FS 4 dan FS 5 dimana suhu turun dari rata-rata di atas $30^{\circ} \mathrm{C}$ pada kondisi tanpa fogging system menjadi di bawah $30^{\circ} \mathrm{C}$ dengan menggunakan alat fogging system (Gambar 2B). Pada perlakuan FS 1 terlihat bahwa terjadi peningkatan kelembaban udara dan suhu dibandingkan dengan kontrol. Hal ini dapat terjadi karena penyemprotan kabut air selama 1 menit setiap 30 menit telah mampu meningkatkan kadar air di udara namun belum mampu menurunkan suhu. Karena posisi sungkup plastik yang rapat maka terjadi peningkatan suhu dalam sungkup melebihi suhu udara di luar sungkup plastik. Pada perlakuan FS
5 meskipun menghasilkan peningkatan kelembaban udara dan penurunan suhu tertinggi, namun terjadi kejenuhan tingkat kelembaban di dalam sungkup plastik yang ditandai dengan terjadinya penempelan air pada plastik penutup. Menurut Leconte dan Carron (1988) kelembaban yang tinggi mendekati $100 \%$ diperlukan dalam aklimatisasi bibit karet asal microcutting, namun untuk daerah tropis hal ini menjadi suatu kendala utama aklimatisasi yaitu dapat meningkatkan timbulnya resiko serangan patogen penyebab penyakit tanaman karet.

Berdasarkan hasil yang diperoleh pada perlakuan optimasi alat fogging system tersebut maka selanjutnya untuk pengaturan kelembaban dan suhu aklimatisasi bibit tanaman karet asal SE dalam sungkup plastik di rumah kaca di pilih perlakuan FS 4 yaitu pengabutan selama 10 menit setiap 1 jam dan di atas sungkup plastik di bawah atap rumah kaca di tutup dengan paranet untuk mengurangi intensitas cahaya sehingga kelembaban udara di atas $90 \%$ dan suhu di bawah $30^{\circ} \mathrm{C}$ dapat tercapai. Keadaan kelembaban yang tinggi dan hampir jenuh air dan suhu yang tidak terlalu tinggi dalam sungkup plastik tersebut diperlukan agar laju transpirasi dapat ditekan sehingga kehilangan air lewat daun dapat dihindari sebelum akar planlet mampu menyerap air dari media pertumbuhan. Hal ini sesuai dengan yang dijelaskan oleh Pospisilova et al. (1999) 


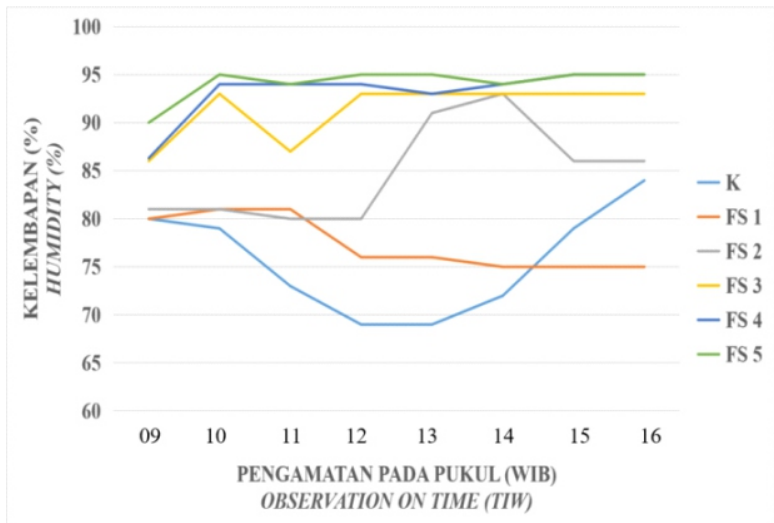

A

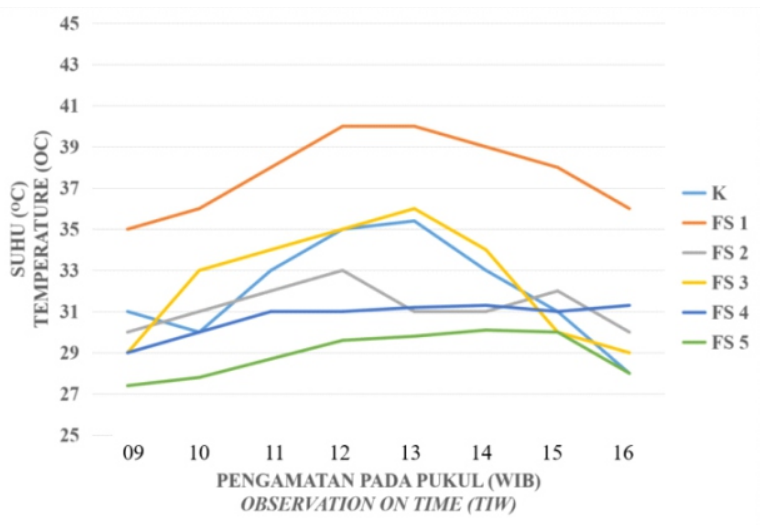

B

Gambar 2. Kelembaban udara (A) dan suhu (B) di dalam sungkup plastik di rumah kaca Pusat Penelitian Karet, Sembawa dari pukul 09.00 - 16.00 WIB pada berbagai perlakuan interval waktu fogging system.

Figure 2. Air humidity (A) and temperature (B) in plastic tunnel at green house of Indonesian Rubber Research Institute, Sembawa from 9 am - 4 pm (Western Indonesian Time) on several interval of time of fogging system.

bahwa pada kondisi in vitro, lapisan kutikula pada jaringan epidermis dan fungsi stomata tanaman kurang berkembang, sehingga pada saat dipindah ke lingkungan ex vitro terjadi peningkatan transpirasi daun yang dapat mengakibatkan kelayuan dan kematian tanaman. Untuk menghindari hal tersebut, diperlukan pengaturan kondisi iklim terutama intensitas cahaya rendah, kelembaban udara tinggi dan suhu rendah yang akan membantu tanaman beradaptasi dengan lingkungan luar secara perlahanlahan. Pada kondisi tersebut kutikula akan berkembang secara bertahap dan stomata akan meregulasi kehilangan air secara lebih efektif.

Pada tahap aklimatisasi, sistem perakaran dan koneksi jaringan floem dan xilem antara akar dengan batang juga belum dapat berfungsi secara sempurna sehingga meskipun ketersediaan air di media tanam cukup, namun belum dapat dimanfaatkan secara optimal oleh tanaman (Filia et al., 1998). Ketersediaan air yang berlebihan di media tanam dalam kondisi seperti itu dapat menjadi ancaman bagi tanaman akibat terjadinya penyerapan air yang tidak sempurna sehingga terbentuk rongga udara di jaringan xilem yang mengakibatkan terjadinya embolism (Montoro, komunikasi pribadi). Hal ini dapat diatasi dengan peningkatan kelembaban udara yang tinggi yang akan membantu meningkatkan potensial air di tanaman. Pengontrolan terhadap transpirasi daun dan batang pada tahap awal tranfer tanaman dari in vitro ke ex vitro merupakan kunci utama keberhasilan tahap aklimatisasi (Seon et al., 2012).

\section{Pengaruh Komposisi Media Tanam terhadap Aklimatisasi Bibit Karet Asal SE dalam Sungkup Plastik di Rumah Kaca}

\section{Kemampuan Tanaman Bertahan Hidup}

Gambar 3 menunjukkan kondisi tanaman pada saat penanaman. Tanaman dalam keadaan segar setelah 1 minggu perjalanan pengiriman dari CIRAD, Perancis (Gambar 3A) ke Pusat Penelitian Karet, Indonesia dan pertumbuhan tanaman relatif seragam pada saat penanaman (Gambar 3B).

Pemeliharaan bibit tanaman karet dalam sungkup plastik dilakukan selama 2 bulan. Hal ini dilakukan berdasarkan SOP aklimatisasi bibit tanaman karet asal SE yang dilakukan di CIRAD, Perancis (Dessaily, komunikasi pribadi) dan berbagai 

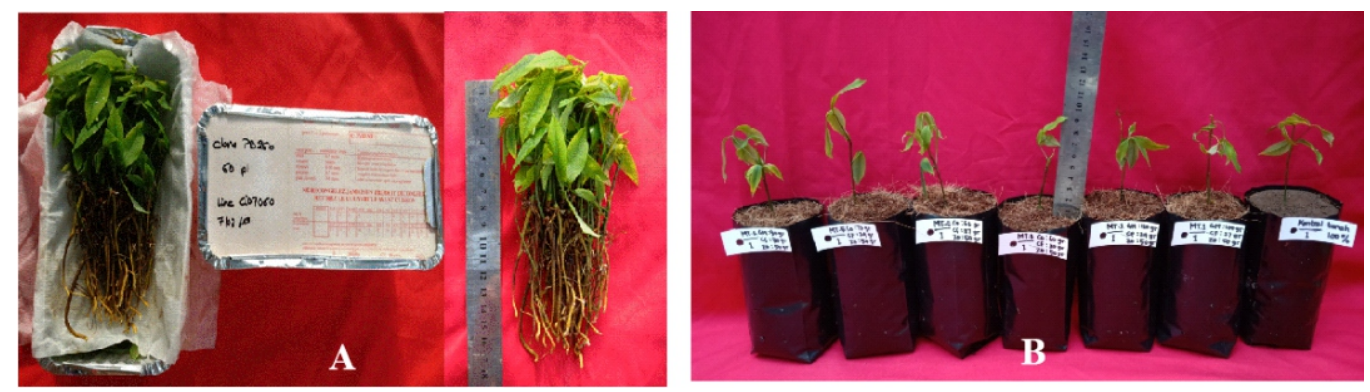

Gambar 3. Kondisi kesegaran (A) dan keseragaman pertumbuhan bibit tanaman karet asal ES pada saat penanaman dengan berbagai komposisi media tanam (B)

Figure 3. Freshness (A) and growth uniformity of rubber planting material originating from $S E$ on planting periode used several composition of planting media (B)

referensi aklimatisasi tanaman karet yang sudah dipublikasikan. Sumaryono et al. (2012) melaporkan bahwa persentase tertinggi bibit karet asal microcutting bertahan hidup pada tahap aklimatisasi yaitu diperoleh pada kondisi pemeliharaan dalam sungkup plastik selama 1,5 bulan pada kondisi kelembaban $70 \%$ dan suhu berkisar $23-32^{\circ} \mathrm{C}$. Hasil penelitian tersebut menunjukkan bahwa terdapat kecenderungan peningkatan persentase bertahan hidup tanaman seiring dengan penambahan waktu penyungkupan. Berdasarkan informasi tersebut maka pada penelitian ini dilakukan penyungkupan selama dua bulan dengan harapan tanaman dapat lebih beradaptasi dengan kondisi luar sehingga persentase tanaman bertahan hidup lebih tinggi.

Pengamatan selama dua bulan tahap aklimatisasi dimana tanaman dipelihara di dalam sungkup plastik dengan kondisi kelembaban yang dikendalikan di atas $90 \%$ dan suhu di bawah $30^{\circ} \mathrm{C}$ (Perlakuan FS 4) menunjukkan bahwa rata-rata kemampuan bibit tanaman bertahan hidup adalah sebesar $83,8 \%$. Tingkat keberhasilan bertahan hidup ini lebih baik dibandingkan dengan kemampuan bertahan hidup bibit karet asal microcutting selama 1,5 bulan dalam sungkup plastik seperti yang dilaporkan oleh Sumaryono et al. (2012) dan Sinta et al (2013) yaitu sebesar 73,3\% dan $80 \%$. Demikian juga dengan hasil yang dilaporkan oleh Sanguansermsri et al. (2015) bahwa keberhasilan hidup aklimatisasi planlet asal perbanyakan dari eksplan tunas nodular mencapai $80 \%$. Hal ini diduga karena kondisi bibit tanaman yang berbeda, dimana bibit asal SE pada penelitian ini memiliki perakaran yang lebih baik dibandingkan dengan bibit asal microcutting. Selain itu perbaikan terhadap proses pengaturan suhu dan kelembaban dalam sungkup plastik juga sudah dilakukan sehingga kondisi iklim di dalam sungkup plastik relatif stabil.

Chandra et al. (2010) menjelaskan bahwa selain manipulasi kondisi iklim lingkungan ex vitro, tingkat keberhasilan tanaman bertahan hidup pada tahap aklimatisasi juga dapat dilakukan dengan melakukan pra aklimatisasi secara in vitro sebelum tanaman ditansfer ke lingkungan ex vitro yang bertujuan agar tanaman dapat tumbuh secara photoautotrophic. Upaya tersebut dilakukan dengan cara memelihara tanaman pada media buatan bebas gula dengan memberi ventilasi udara, peningkatan kandungan $\mathrm{CO}_{2}$, peningkatan intensitas cahaya dan pengurangan unsur makro pada media tumbuh. Dengan demikian terjadi peningkatan adaptasi fisiologi dan morfologi tanaman seperti perkembangan akar, perlindungan terhadap kehilangan air melalui fungsi stomata (memperlambat kecepatan transpirasi), peningkatan asimilasi $\mathrm{CO}_{2}$ (meningkatkan kecepatan fotosintesis), pembentukan daun baru, memperluas permukaan daun dan peningkatan biomassa daun dan akar (Xiao et al., 2011; Hoang et al., 2017; Tisarum et al., 2018).

Tabel 3 menunjukkan bahwa komposisi media mempengaruhi kemampuan bertahan hidup bibit tanaman karet asal SE selama 2 bulan dalam sungkup 
Gambar 3. Kondisi kesegaran (A) dan keseragaman pertumbuhan bibit tanaman karet asal ES pada saat penanaman dengan berbagai komposisi media tanam (B)

Figure 3. Freshness (A) and growth uniformity of rubber planting material originating from $S E$ on planting periode using several composition of planting media (B)

\begin{tabular}{|c|c|c|}
\hline $\begin{array}{l}\text { Perlakuan } \\
\text { Treatment }\end{array}$ & $\begin{array}{l}\text { Komposisi media tanam } \\
\text { Composition of planting media }\end{array}$ & $\begin{array}{c}\text { Persentase hidup } \\
\text { Percentage of survival } \\
(\%)\end{array}$ \\
\hline Kontrol & $100 \%$ tanah & $90,00 \mathrm{a}$ \\
\hline MT 1 & cf $60 \%+$ gambut $30 \%+$ zeolit $10 \%$ & $90,00 \mathrm{a}$ \\
\hline MT 2 & cf $50 \%+$ gambut $40 \%+$ zeolit $10 \%$ & $90,00 \mathrm{a}$ \\
\hline MT 3 & cf $40 \%+$ gambut $50 \%+$ zeolit $10 \%$ & $86,67 \mathrm{ab}$ \\
\hline MT 4 & cf $60 \%+$ cp $30 \%+$ zeolit $10 \%$ & $83,33 \mathrm{ab}$ \\
\hline MT 5 & cf $50 \%+$ cp $40 \%+$ zeolit $10 \%$ & $70,00 \mathrm{~b}$ \\
\hline MT 6 & cf $40 \%+$ cp $50 \%+$ zeolit $10 \%$ & $76,67 \mathrm{~b}$ \\
\hline
\end{tabular}

Keterangan (Remarks) $: \mathrm{cf}=$ cocofiber $; \mathrm{cp}=$ cocopeat

plastik. Media tanah sebagai kontrol pembanding menunjukkan hasil persentase tertinggi tanaman bertahan hidup. Hal utama yang dikhawatirkan dalam penggunaan tanah sebagai media tumbuh aklimatisasi bibit karet asal kultur jaringan adalah ketersediaan top soil yang sudah terbatas dan tingginya kontaminasi patogen dalam media terutama patogen penyebab penyakit jamur akar putih. Berdasarkan hasil yang diperoleh terlihat bahwa dengan penanganan yang baik seperti menghindari penggunaan media tanah yang berasal dari perkebunan karet dan penggunaan fungisida sebelum media digunakan dapat membantu pencegahan terhadap serangan patogen.

Selain itu campuran media cocofiber, gambut dan zeolit juga memberikan persentase tanaman bertahan hidup yang sama dan tidak berbeda nyata dengan media tanah. Hasil tersebut kemungkinan disebabkan kemampuan campuran media untuk memberikan kelembaban dan aerasi yang cukup pada tanaman yang membantu meningkatkan pertumbuhan dan fungsi akar dengan baik. Hasil yang diperoleh pada penelitian ini sesuai dengan SOP yang disarankan oleh CIRAD bahwa penggunaan campuran $60 \%$ cocofiber, $30 \%$ gambut dan $10 \%$ zeolit merupakan media terbaik untuk aklimatisasi bibit tanaman karet asal SE. Hasil tersebut dapat dijadikan sebagai bahan pertimbangan bahwa pada kondisi yang sulit untuk mendapatkan top soil, penggunaan media campuran cocofiber, gambut dan zeolit dapat menjadi alternatif pengganti media tanah.

Gambar 4 menunjukkan jumlah bibit karet asal SE yang bertahan hidup selama tahap aklimatisasi, dua bulan dalam sungkup plastik dan satu bulan setelah sungkup plastik dibuka secara bertahap pada berbagai komposisi media tumbuh. Kemampuan tanaman bertahan hidup pada bulan pertama cukup tinggi dengan ratarata kematian tanaman hanya berkisar 4,5\% dan meningkat menjadi $20,95 \%$ pada bulan kedua. Berdasarkan hasil tersebut tahap aklimatisasi bibit karet asal SE ini dianggap cukup berhasil karena mampu mempertahankan tanaman tetap tumbuh dengan baik. Peningkatan kematian yang cukup tingggi mencapai 32,38\% terjadi pada bulan ketiga saat sungkup plastik mulai dibuka secara bertahap setiap minggu yaitu selama 1 jam, 3 jam, 5 jam dan dibuka seluruhnya pada satu bagian sisi penutup. Hal ini kemungkinan disebabkan karena terjadinya perubahan kondisi lingkungan yang cukup besar dari kondisi lingkungan suhu dan kelembaban terkontrol pada kondisi yang tidak terkontrol yang mengakibatkan tanaman mengalami stress. Menurut Sumaryono et al (2012) waktu terbaik memelihara bibit tanaman karet asal microcutting dalam sungkup plastik adalah 6 minggu dengan daya hidup planlet yang 


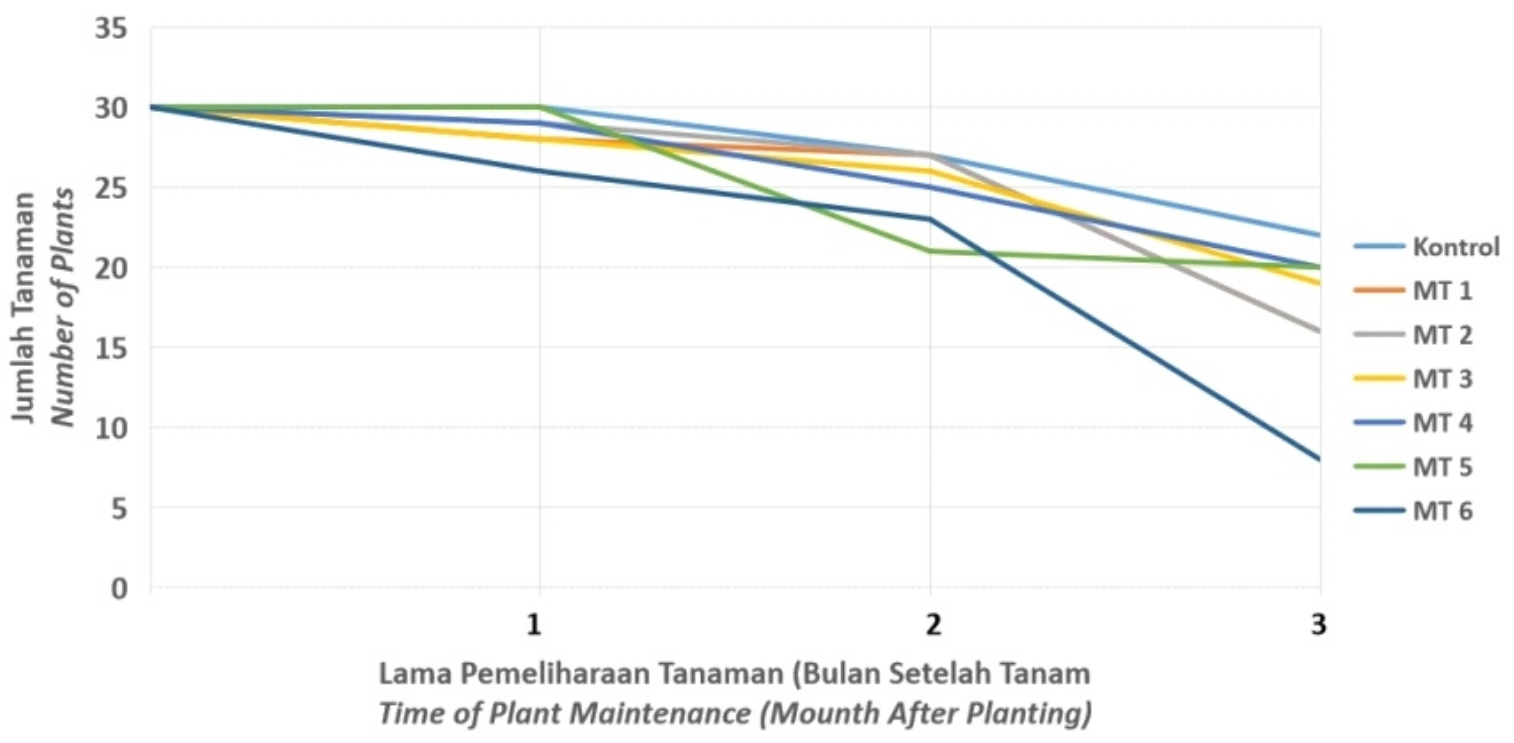

Gambar 4. Pengaruh komposisi media tanam terhadap jumlah tanaman bertahan hidup pada tahap aklimatisasi di dalam sungkup plastik di rumah kaca

Figure 4. Effect of composition of planting media to number of plants survive at acclimatization stage in plastic tunnel at green house

mencapai $73,3 \%$. Hal ini dengan pertimbangan bahwa setelah 6 minggu tidak diperlukan lagi penyungkupan karena tanaman telah mampu menyerap air dan hara dari media tumbuh yang ditandai dengan tumbuhnya daun baru. Berbeda dengan penelitian tersebut, pada penelitian ini tanaman mengalami pengguguran hampir seluruh daunnya pada saat sungkup plastik dibuka dan sebagian besar tanaman tidak mampu bertahan hidup pada kondisi tersebut. Berdasarkan kondisi tersebut diduga pada saat kelembaban udara menurun tanaman harus menyerap air dari media, sedangkan tanaman belum mampu untuk melakukan hal tersebut sehingga terjadilah embollism yang mengakibatkan kematian pada tanaman.

\section{Pertumbuhan Tinggi, Diameter dan Jumlah Daun Tanaman}

Pertumbuhan bibit tanaman karet asal SE selama aklimatisasi dalam sungkup plastik di rumah kaca terlihat pada Gambar 5. Pengukuran pertumbuhan berdasarkan parameter tinggi, diameter dan jumlah daun seluruh tanaman dilakukan setelah tanaman dipelihara selama 2 bulan dalam sungkup plastik dan 1 bulan setelah sungkup plastik dibuka bertahap, sedangkan tinggi, diameter dan jumlah daun awal tanaman saat penanaman hanya dihitung pada 10 sampel yang diambil secara acak untuk menghindari terjadinya kerusakan dan stres pada tanaman, dimana rata-rata tinggi, diameter dan jumlah daun awal tanaman ditanam adalah $58 \mathrm{~cm}, 1,29$ $\mathrm{cm}$ dan 5,2. Berdasarkan pengamatan visual yang dilakukan terlihat bahwa pertumbuhan tanaman selama 2 bulan dalam sungkup plastik tidak terlalu berbeda dibandingkan dengan rata-rata tinggi, diameter dan jumlah daun tanaman pada saat penanaman. Diduga selama dua bulan tahap aklimatisasi tersebut tanaman masih dalam tahap adaptasi, belum sepenuhnya kearah pertumbuhan. Selama dua bulan tersebut terlihat tanaman dalam keadaan segar dan secara umum jumlah daun masih tetap seperti diawal tanam. Perubahan kondisi tanaman mulai terlihat pada saat masuk bulan ketiga setelah tanam disaat sungkup plastik mulai dibuka secara bertahap. Pada minggu pertama sungkup plastik dibuka, sebagian besar daun mulai menguning dan gugur. Namun diakhir bulan ketiga daun-daun baru mulai tumbuh.

Penggunaan berbagai komposisi media tidak berpengaruh nyata terhadap pertumbuhan tinggi, diameter batang dan jumlah daun tanaman selama dua bulan dalam sungkup plastik. Pengaruh media 

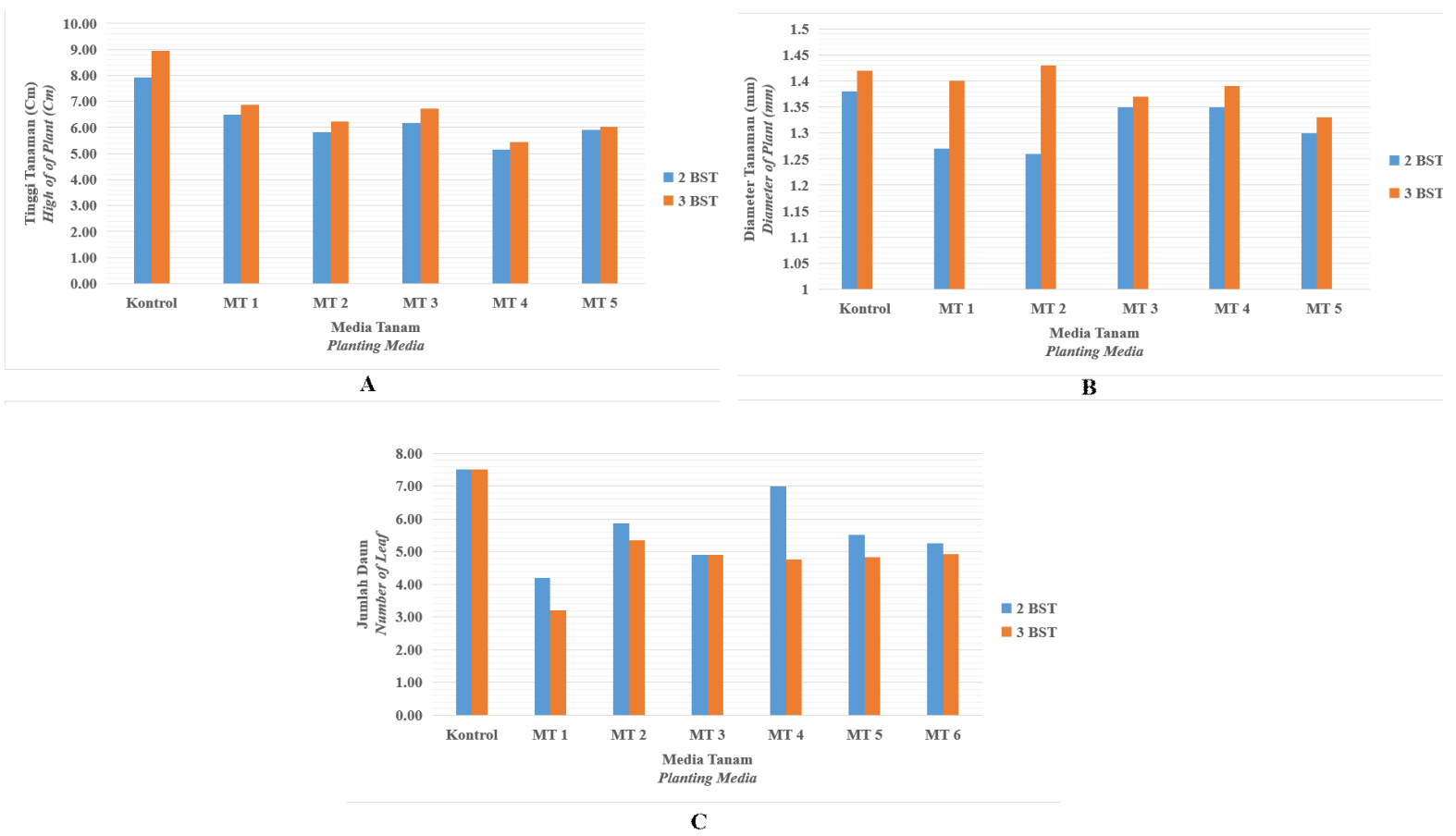

Gambar 5. Pertumbuhan tinggi (A), diameter (B) dan jumlah daun (C) bibit tanaman karet asal SE pada berbagai media tanam selama tahap aklimatisasi dalam sungkup plastik di rumah kaca

Figure 5. Growth of height (A), diameter $(B)$ ad number of leafs of rubber planting material originated from SE in several media composition at acclimatization stage in plastic tunnel at green house

Tabel 4. Pengaruh berbagai komposisi media terhadap pertumbuhan tinggi, diameter dan jumlah daun tanaman pada tahap aklimatisasi di rumah kaca

Table 4. Effect of media composition to high, diameter and number of leave of planlets on acclimatization stage at green house

\begin{tabular}{|c|c|c|c|c|c|c|}
\hline \multirow{3}{*}{$\begin{array}{l}\text { Perlakuan } \\
\text { Treatment }\end{array}$} & \multicolumn{2}{|c|}{$\begin{array}{l}\text { Tinggi } \\
\text { Height } \\
\text { (cm) }\end{array}$} & \multicolumn{2}{|c|}{$\begin{array}{c}\text { Diameter } \\
\text { Diameter } \\
(\mathrm{cm}) \\
\end{array}$} & \multicolumn{2}{|c|}{$\begin{array}{l}\text { Jumlah daun } \\
\text { Number of leaves }\end{array}$} \\
\hline & $2 \mathrm{BST}$ & $3 \mathrm{BST}$ & $2 \mathrm{BST}$ & $3 \mathrm{BST}$ & $2 \mathrm{BST}$ & $3 \mathrm{BST}$ \\
\hline & $2 M A P$ & $3 M A P$ & $2 M A P$ & $3 M A P$ & $2 M A P$ & $3 M A P$ \\
\hline Kontrol & $7,92 \mathrm{tn}$ & $8,95 a$ & $1,38 \mathrm{tn}$ & $1,42 \mathrm{tn}$ & $7,50 \mathrm{tn}$ & $7,50 \mathrm{tn}$ \\
\hline MT 1 & 6,50 & $6,88 \mathrm{ab}$ & 1,27 & 1,40 & 4,20 & 3,20 \\
\hline MT 2 & 5,83 & $6,23 b$ & 1,26 & 1,43 & 5,85 & 5,35 \\
\hline MT 3 & 6,17 & $6,73 \mathrm{ab}$ & 1,35 & 1,37 & 4,89 & 4,89 \\
\hline MT 4 & 5,14 & $5,44 b$ & 1,35 & 1,39 & 7,00 & 4,75 \\
\hline MT 5 & 5,92 & $6,02 b$ & 1,30 & 1,33 & 5,50 & 4,83 \\
\hline MT 6 & 5,59 & $6,06 \mathrm{~b}$ & 1,22 & 1,23 & 5,26 & 4,91 \\
\hline
\end{tabular}

Keterangan (Remaks) : tn=tidak berbeda nyata (not significantly different)

$B S T$ : bulan setelah aklimatisasi (MAP: month after acclimatization) 

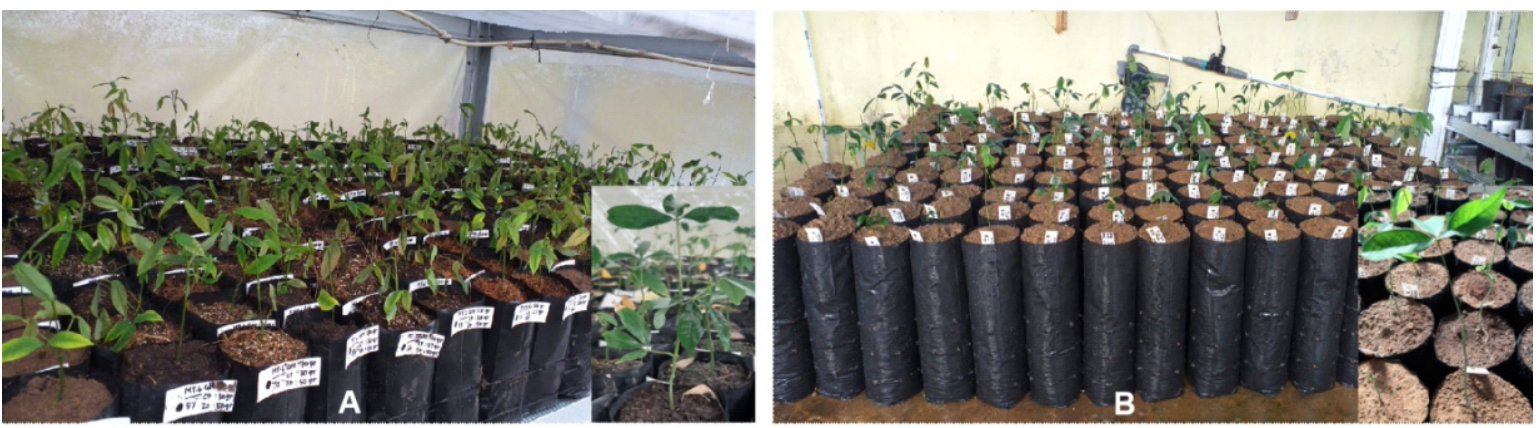

Gambar 6. Pertumbuhan planlet karet asal SE pada awal penanaman (A) dan tiga bulan setelah aklimatisasi (B)

Figure 6. Growth of plantlets origined from SE on early planting (A) and three months after acclimatization (B)

terhadap pertumbuhan tinggi tanaman baru terlihat setelah satu bulan sungkup plastik dibuka secara bertahap (Tabel 4). Hal tersebut kemungkinan terjadi karena akar tanaman SE belum tumbuh sehingga komposisi media tidak berpengaruh nyata terhadap pertumbuhan tanaman selama dua bulan. Secara umum pertumbuhan tanaman pada media kontrol yang menggunakan tanah $100 \%$ lebih baik dibandingkan dengan pertumbuhan tanaman pada media lainnya. Penggunaan campuran media cocofiber, gambut dan zeolit secara umum memberikan pengaruh terhadap pertumbuhan tinggi dan diameter tanaman yang lebih baik dibandingkan campuran media cocofiber, cocopeat dan zeolite. Hal tersebut karena gambut mempunyai sifat fisik, kimia, dan biologi yang baik untuk tanaman (Gruda, 2012) sehingga cocok sebagai media tanam. Hasil analisis sifat kimia gambut berdasarkan penelitian tersebut menunjukkan bahwa gambut memiliki kadar C-organik, Nitrogen dan Kapasitas Tukar Kation (KTK) yang tinggi (Tabel 2). Sementara cocopeat dan cocofiber merupakan produk sampingan dari industri pengolahan kelapa yang mempunyai sifat fisik tanah yang baik namun kandungan unsur hara yang rendah (Cahyo et al., 2016).

Selama proses aklimatisasi terlihat bahwa pertumbuhan tinggi dan diameter batang tanaman masih rendah. Pertumbuhan daun baru juga terlihat lambat. Hal ini terlihat pada Tabel 4 dan Gambar 6, dimana jumlah daun tanaman tiga bulan setelah aklimatisasi lebih sedikit dibanding di awal penanaman.

\section{KESIMPULAN DAN SARAN}

Kesimpulan yang dapat ditarik berdasarkan hasil percobaan adalah sebagai berikut :

1. Pengaturan kondisi suhu dan kelembaban udara lingkungan tumbuh telah berhasil dilakukan dengan kondisi suhu di bawah $30^{\circ} \mathrm{C}$ dan kelembaban di atas $90 \%$.

2. Komposisi media tumbuh berpengaruh terhadap kemampuan bertahan hidup bibit karet asal SE selama dua bulan dalam sungkup plastik. Tanah merupakan media terbaik untuk aklimatisasi bibit karet asal SE dan diikuti oleh campuran media cocofiber, gambut dan zeolit dengan persentase tanaman hidup mencapai $90 \%$.

3. Penggunaan berbagai komposisi media tidak berpengaruh nyata terhadap pertumbuhan tinggi, diameter batang dan jumlah daun tanaman selama dua bulan tanaman dalam sungkup plastik. Pengaruh media terhadap tinggi tanaman terlihat setelah 1 bulan sungkup plastik dibuka secara bertahap.

4. Media alternatif pengganti terbaik pada kondisi ketersediaan top soil yang terbatas untuk digunakan dalam aklimatisasi bibit karet asal SE adalah campuran $50-60 \%$ cocofiber, $30-40 \%$ gambut dan $10 \%$ zeolit. 
Saran yang dapat diungkapan penulis untuk kegiatan riset berikutnya adalah perlu dilakukan optimasi metode terkait dengan waktu pembukaan sungkup plastik setelah 2 bulan aklimatisasi.

\section{UCAPAN TERIMA KASIH}

Terima kasih diucapkan kepada Dr. Pascal Montoro, CIRAD, Perancis atas diskusi dan masukan yang diberikan kepada Penulis selama pelaksanaan kegiatan penelitian.

\section{DAFTAR PUSTAKA}

Aronen, T. (2016). From Laboratory to Field Current State of Somatic Embryogenesis in Scot Pine. In: Park Y. S., J. M. Bonga \& H. K. Moon (eds). Vegetative Propagation of Forest Trees. South Korea : National Institute of Forest Science.

Barpete, S., Khawar, K.M., \& Özcan, S. (2014). Differential competence for in vitro adventitous rooting of grass pea (Lathyrus sativus L.). Plant Cell, Tissue and Organ Culture, 119(1), 39-50. https://doi.org/10.1007/s 11240 014-0512-6

Cahyo, A.N., Saputra, J., Stevanus, C.T., \& Sahuri. (2016). Penggunaan root trainer untuk meningkatkan pertumbuhan bibit karet. Jurnal Penelitian dan Pengembangan Pertanian, $35(1), 17-24$. https://doi.org/ 10.21082/jp3.v35n1. 2016.p17-24

Cardinal, Á.B.B, Gonçalves, P.S., \& Martins, A.L.M. (2007). Stock-scion interactions on growth and rubber yield of Hevea brasiliensis. Scientia Agricola, 64(3), 235-240. https://doi.org/10.1590 /S0103-90162007000300004
Chandra, S., Bandopadhyay, R., Kumar, V., \& Chandra, R. (2010). Acclimatization of tissue cultured plantlets: from laboratory to land. Biotechnology Let ter, 32, $1199-1205$. https: / / doi.org/ 10.1007/s 10529 010-0290-0

Carron, M.P., \& Enjarlic, F. (1985). Somatic embryogenesis from inner integument of the seed of Hevea brassiliensis Muell. Arg. CR. Academic Science, 300, 653-658.

Clément-Demange, A., Priyadarshan, P.M., Tran, T.T.H., \& Venkatachalam P. (2007). Hevea Rubber Breeding and Genetics. Plant Breeding Reviews Volume 29. Ed. Janick, J. Hoboken, New Jersey: John Wiley \& Sons. https://doi.org/10.1002/978047016 8035.ch4

Dibi, K., Boko, C., Obouayeba, S.M., Dea G.B., Carron, M.P., \& Anno, A.P. (2010). Field growth and rubber yield of in vitro micropropagated plants of clones PR 107, IRCA 18 and RRIM 600 of Hevea brasiliensis (Müll.-Arg.). Agriculture and Biology Journal of North A merica, 1(6), $1291-1298$. https://doi.org/10.5251/abjna.2010. 1.6.1291.1298

Dickson, I., Okere, A., Elizabeth, J., Mary, O., Olatunde, F., \& Abiodun, S. (2011). In vitro culture of Hevea brasiliensis (rubber tree) embryo. Journal of Plant Breeding and Crop Science, 3(9), 185189.

El-Zeiny, O.A.H., El-Behairy, U.A., Zocchi, G., \& Rashwan, M. (2013). Commercial production of globe artichoke (Cynara scolymus L.) in vitro. Egyptian Journal of Agriculture Research, 91(3), 9931007. 
Gireesh, T., Varghese, Y.A., Woeste, K.E., Mercykutty, V.C., \& Marattukalam, J.G. (2012). Effect of monoclonal and assorted seedling rootstocks on long term growth and yield of Hevea clones. Silvae Genetica, 61(1), 52-57. https://doi.org/10.1515/sg-20120007

Goncalves, P.S., \& Martins, A.L.M. (2002). Combining ability effect of clonal rootstock and scions in rubber trees (Hevea brasiliensis). Crop Breeding and Applied Biotechnology, 2(3), 445-452. https://doi.org/10.12702 / 1984 7033.v02n03a16

Gruda, N. (2012). Current and future perspective of growing media in Europe. Acta Horticulturae, 960, 37-43. https://doi.org/10.17660 /ActaHortic.2012.960.3

Hazarika, B.N. (2003). Acclimatization of tissue-cultured plants. Current Science, 85(12), 1704-1712.

Hazarika, B.N., Jaime, A., Teixeira, S., \& Talukdar, A. (2006). Acclimatization of in vitro cultured plants: methods, physiology and genetics. Floriculture, Ornamental and Plant Biotechnology, 2, 427-438.

Hoang, N.N., Kitaya, Y., Morishita, T., Endo, R., \& Shibuya, T. (2017). A comparative study on growth and morphology of wasabi plantlets under the influence of the micro-environment in shoot and root zones during photoautotrophic a n d p h o t o m ixot roph i c micripropagation. Plant Cell, Tissue and Organ Culture, 130, 255-263. https://doi.org/10.1007/s 11240 017-1219-2

Jayasree, P.K., Asohan, M.P., Sobha, S., Ammal, S., Rekha, K., Kala, R.G., Jayasree, R., \& Thulasepdharan, A. (1999). Somatic embryogenesis and plant regeneration from immature anthers of Hevea brassiliensis (Muell.) Current Science, 76(9), 122 - 1245.
Jayashree, R., Rekha, K., Sushamakumari, S., Sobha, S., \& Thulaseedharan, A. (2011). Unfertilized ovule - a potential explant for somatic embryogenesis in Hevea brasiliensis. Proceedings of IRRDB International Rubber Conference. Chiang Mai, Thailand: IRRDB

Kaur, H.A., \& Goyal, M.D. (2011). Optimization of potting mixture for hardening of in vitro raised plants of Tylophora indica to ensure high survival percentage. International Journal Medical Aromatic Plants, 1(2), 83-88.

Lardet, L., Dessailly, F., Carron, M.P., Rio, M., Ferrière, N., \& Montoro, P. (2009). Secondary somatic embryogenesis in Hevea brasiliensis (Müll. Arg.): An alternative process for long-term somatic embryogenesis. Journal of Rubber Research, 12(4), 215-227.

Lavanya, M., Venkateshwarlu, B., \& Devi, B.P. (2009). Acclimatization of neem microshoots adaptable to semi-sterile conditions. Indian Journal of Biotechnology, 8, 218-222.

Leconte, A., \& Carron, M.P. (1988). Acclimatization of microcuttings from rubber (Hevea brasiliensis): problem and perspective. In J.L. Jacob \& J.C. Prevot (eds). Compte-Rendu du Colloque Exploitation-Physiologie et Amelioration de Hevea. Colloque Hevea IRRDB. IRCA/CIRAD (p. 499-503). Paris, France: CIRAD.

Li, H.L, Guo, D., Zhu, J.H., Wang, Y., Chen, X.T., \& Peng, S.Q. (2016). Comparative transcriptome analysis of latex reveals molecular mechanisms underlying increased rubber yield in Hevea brasiliensis self-rooting juvenile clones. Frontier Plant Science, 7, 1204. https://doi.org/10.3389/fpls.2016.0 1204 
Mayati, N.C.H., \& Jamnah, A.R. (2014). Induction of shoots and roots from vegetative tissue culture Hevea brasiliensis RRIM 2000. Journal Tropical Plant Physiology, 6, 1-9.

Montoro, P., Teinseree, N., Rattana, W., Kongsawadworakul, P., \& MichauxFerriere, N. (2000). Effect of exogenous calcium on Agrobacterium tumefaciens-mediated gene transfer in Hevea brassiliensis (rubber tree) friable calli. Plant Cell Report, 19(9), 851-855. https://doi.org/10.1007 /s002990000208

Monteuuis, O. (2016). Micropropagation and production of forest trees. In: Vegetative propagation of forest trees. Part 1: Development and trends in vegetative propagation of forest trees, Eds Y. S. Park, J. M. Bonga, H. K. Moon. South Korea: NIFOS.

Mignon, E., \& Werbrouck S. (2018) Somatic embryogenesis as key technology for shaping the rubber tree of the future. Frontier in Plant Science, 9, 1804. https://doi.org/10.3389/fpls.2018.0 1804

Pospisilova, J., Ticha, I., \& Kadlecek, P. (1999). Acclimatization of micropropagated plants to ex vitro conditions. Biology Plant, 42, 481-497. https://doi.org/10.1023/A: 10026882 08758

Sanguansermsri, M., Khamthup, P., Meechana, K., Wongsawad, M., \& Buddharaksa, P. (2015). In vitro embryo culture. Naresuan Phayao Journal, 8, 155-158.

Saputra, J., Stevanus, C. T., Ardika, R., \& Wijaya, T. (2018). Pengujian beberapa alternatif teknik penanaman tanaman karet di lahan gambut. Jurnal Penelitian Karet, 36(2), 117-126. https:/ / doi.org/ 10.22302/ppk.jpk.v3 $6 i 2.595$
Seon, J., Cui, Y., Kozai, T., \& Paek, K.Y. (2012). Influence of in vitro growth conditions on photosynthetic competence and survival rate of Rehmannia glutinosa plantlets during acclimatization period. Plant Cell Tissue and Organ Culture, 61, 135142. https://doi.org/10.1023 /A: 1006473223286

Singh, C.R. (2018). Review on problems and its remedy in plant tissue culture. Asian Journal of Biology Science, 11(4), 165-172. https://doi.org/10.3923 /ajbs.2018.165.172

Sinta, M.M., Haris, N., \& Sumaryono. (2013). Pengaruh periode pra-kondisi dan penutupan sungkup terhadap daya hidup planlet karet. Menara Perkebunan, 81(1), 16-22. http://dx.doi.org/10.22302/iribb.jur. mp.v81i1.47

Sumaryono., Sinta, M.M., \& Hars, N. (2012). Daya hidup planlet karet asal in vitro microcutting pada berbagai periode penutupan sungkup plastik dan komposisi media tumbuh. Menara Perkebunan, 80(1), 25-31. http: / /dx.doi.org/10.22302/iribb.jur. mp.v80i1.46

Tahardi, J.S. (1998). Plant regeneration in Hevea brasiliensis via somatic embryogenesis. Menara Perkebunan, 66(1), 1-8.

Tisarum, R., Samphumphung, T., Theerawitaya, C., Prommee, W., \& Cha-um, S. (2018). In vitro photoautotrophic acclimatization, direct transplantation and ex vitro adaptation of rubber tree (Hevea brasiliensis). Plant Cell, Tissue and Organ Culture, 133, 215-223. http: / /dx.doi.org/ 10.1007 / s 11240 017-1374-5 
Wan, A.R., Gandhimathi, H., Rohani, O., \& Paranjothy, K. (1982). Recent development in tissue culture of Hevea. Singapore : COSTED.

Xiao, Y., Niu, G., \& Kozai, T. (2011). Development and application of photoautotrophic micropropagation plant system. Plant Cell, Tissue and Organ Culture, 105, 149158. https: / / doi.org/10.1007/s 11240010-9863-9
Zhou, Q.N., Jiang, Z.H., Huang, T.D., Li, W.G., Sun, A.H., Dai, X.M., \& Li, Z. (2010). Plant regeneration via somatic embryogenesis from root explants of Hevea brasiliensis. African Journal of Biotechnology, 9(48), 8168-8173. http://dx.doi.org/10.5897/AJB10.96 9 